\title{
Praćenje farmakološki aktivnih tvari u mlijeku u Europskoj uniji
}

\author{
N. Bilandžic ${ }^{*}$, I. Varenina, B. Solomun Kolanović, Đ. Božić Luburić i I. Varga
}

\section{Sažetak}

Proizvodnja sigurnog i kvalitetnog mlijeka ključni je aspekt pravilnog javnog zdravstva u Europskoj uniji (EU). Česta uporaba farmakološki aktivnih tvari u kliničkoj praksi na govedarskom farmama uzrokuje pojavu njihovih ostataka u različitim prehrambenim proizvodima uključujući mlijeko. Najčešće korišteni lijekovi u mliječnoj industriji su antibiotici tetraciklini i beta-laktami protiv patogenih uzročnika mastitisa. Primjena veterinarskih lijekova mora biti pažljivo optimizirana kako bi se zaštitilo zdravlje potrošača od mogućih štetnih toksičnih učinaka. Također, veliki problem je i razvoj rezistencije $u$ potrošača koji uzrokuje neuspjeh antibiotskih terapija, posebice protiv opasnih patogenih sojeva mikroorganizama. Danas većina članica EU pokazuje tendenciju povećanja proizvodnje mlijeka. Najveći proizvođači mlijeka u EU su Njemačka, Francuska i Ujedinjeno Kraljevstvo. U Hrvatskoj je u zadnje 3 godine vidljiva tendencija pada proizvodnje mlijeka. Članice EU teže kontroli ostataka farmakološki aktivnih tvari u mlijeku primjenom selektivnih, osjetljivih i preciznih analitičkih metoda. Tekućinska kromatografija povezana $\mathrm{s}$ tandemskom masenom spektrometrijom (LC-MS/MS) je najčešće korištena instrumentalna analitička tehnika za određivanje ostataka tih tvari u mlijeku. Danas su razvijene multimetode primijenom LC-MS/ MS koje omogućuju identifikaciju 160 i više spojeva. U svrhu zaštite zdravlja potrošača članice EU provode kontrolu farmakološki aktivnih tvari u mlijeku u okviru nacionalnih planova praćenja njihovih ostataka (NPPR). Kontrola farmakološki aktivnih tvari temelji se na definiranim najvećim dopuštenim količinama ostataka tih tvari (NDK). Europska agencija za sigurnost hrane (EFSA) prikuplja podatke kontrole svih članica EU analiziranih $\mathrm{u}$ okviru NPPR te svake godine prilaže zajedničko izvješće. U okviru planova NPPR država članica EU tijekom 2015., 2016. i 2017. ustvrdeno je 0,115 \%, 0,128 \% i 0,304 \% nesukladnih rezultata za farmakološki aktivne tvari. Najveći broj nesukladnih rezultata odnosio se na skupinu antibakterijskih tvari (B1) i nesteroidnih protuupalnih lijekova (B2e). U skupini antibakterijskih tvari ustvrđeno je ukupno 48,2\% nesukladnih tvari beta-laktama u sve tri godine ukupno. U 2017. godini najveći broj nesukladnih rezultata se odnosio na nesteroidne protuupalne lijekove (54,5\%), odnosno u toj skupini lijekova 90,5\% nesukladnih je ustvrđeno za salicilnu kiselinu.

Ključne riječi: farmakološki aktione tvari, veterinarski lijekovi, mlijeko, kontrola mlijeka, Europska unija

Dr. sc. Nina BILANDŽIĆ* , dipl. ing. biotehnol., znanstvena savjetnica, dr. sc. Ivana VARENINA, dipl. ing. biotehnol., dr. sc. Božica SOLOMUN KOLANOVIĆ, dipl. ing. preh. tehnol., Đurđica BOŽIĆ LUBURIC, dipl. ing. biotehnol., Ines VARGA, mag. prim. kem., Hrvatski veterinarski institut, Zagreb, Hrvatska 


\section{Uvod}

U suvremenoj veterinarskoj praksi, farmakološki aktivne tvari se primijenjuju $\mathrm{u}$ životinja koje proizvode hranu u svrhu liječenja bolesti, za spriječavanje mogućih bolesti odnosno preventivno ili u svrhu postizanja bržeg prirasta $u$ svojstvu promotora rasta. Nijhova primjena $u$ uzgoju životinja i veterini rezultirala je zdravijim i produktivnijim domaćim životinjama te osigurala dobrobit i zdravlje životinja. Danas je više stotina različitih tvari u opticaju u veterinarskoj medicini te djeluju kao antibiotici, antiparazitici, kokcidiostatici, fungicidi ili protuupalni lijekovi (Song i Guo, 2014., Bessaire i sur., 2018.).

Među veterinarskim lijekovima više od $70 \%$ korištenih su antibiotici (Song i Guo 2014.). Njihova globalna potrošnja raste te se smatra da će sa 63151 tona u 2010. godini porasti na 105596 tona do 2030. (Van Boeckel i sur., 2015.). Najčešće primjenjivane skupine antibiotika $u$ veterinarskoj medicini su beta-laktami, tetraciklini, sulfonamidi, fluorokinoloni, makrolidi, linkozamidi i aminoglikozidi (Jank i sur., 2017.).

U mliječnoj industriji najčešće korišteni antibiotici su antimikrobni lijekovi koji se koriste protiv patogenih uzročnika mastitisa (Fisher i sur., 2011.). Goveđi mastitis je endemska bolest te jedna je od najčešćih bolesti koja pogađa mliječno govedo i smanjuje kakvoću mlijeka (Leslie i Petersson-Wolfe, 2012.). Na farmama mliječnih goveda visoka učestalost kliničkog mastitisa te subkliničkog mastitisa predstavlja gospodarski i socijalni problem (Halasa i sur., 2007., Getaneh i sur., 2017.). Povezana je s djelovanjem raznih bakterija što rezultira upalom mliječnih žlijezda. Uporaba antimikrobnih lijekova tijekom razdoblja dojenja je česta pojava u mliječnom govedarstvu (Magon i sur., 2018.). U tu svrhu u proizvodnji mlijeka u svrhu spriječavanja i kontrole mastitisa koriste se tetraciklini te beta-laktamski antibiotici, odnosno penicilini i cefalos- porini (Bourin i Clénet, 2014.). Najčešće se koriste tetraciklini zbog niskih troškova i širokog spektra djelovanja (Kuang i sur., 2009.).

Prisutnost ostataka antibiotika u mlijeku stvara poteškoće u proizvodnji te narušava kvalitetu proizvoda (Mishra i sur, 2011.). Ostatci antibiotika u hrani životinjskog podrijetla stvaraju potencijalnu prijetnju izravnom toksičnošću za ljude. Glavni javno zdravstvi rizici povezani s izlaganjem veterinarskim lijekovima su reakcije preosjetljivosti, karcinogenost, mutagenost, teratogenost i poremećaj normalne flore crijeva (Desmarchelier i sur., 2018.).

Prečesta niska razina izloženosti antibioticima rezultira izmjenom mikroflore i mogućim razvojem rezistencije koji prouzroče neuspjeh antibiotske terapije u kliničkim situacijama (Mishra i sur, 2011., Hassan i sur., 2014.). Naime, danas su infekcije prouzročene bakterijama otpornim na antibiotike $u$ porastu, a otpornost na antibiotike vjerojatno je glavni javno zdravstveni problem. Uporaba ili zlouporaba antibiotika u veterinarskoj medicini, ponajprije na velikim farmama dovela je do nastanka otpornih bakterija $\mathrm{u}$ životinjskom staništu. Taj se rezervoar otpornosti može izravno ili neizravno prenijeti na ljude putem konzumacije hrane i izravnim ili neizravnim kontaktom. Otporne bakterije mogu prouzročiti ozbiljne zdravstvene učinke izravno ili prenošenjem svojstava rezistentnosti na antibiotike na patogene, uzrokujući teško liječenje bolesti i zbog toga viši stupanj obolijevanja i smrtnosti (Economou i Gousia, 2015.). Projekcija smrtnih slučajeva koji su posljedica antimikrobne otpornosti mikroorganizama na razini EU spominje brojku od 25000 svake godine (Desmarchelier i sur., 2018.).

Stoga je zaštita javnog zdravlja od mogućih štetnih učinaka ostataka veterinarskih lijekova od prioriteta za kontrolna tijela Europske unije (EU). 
Neprestano se radi na poboljšanjima analitičkih kapaciteta članica EU potrebnih za praćenje ostataka lijekova od uzgajališta, odnosno od sirovine do gotovih proizvoda, odnosno stola $u$ kućanstvima.

\section{Proizvodnja mlijeka u Europskoj uniji}

U različitim zemljama svijeta potrošnja mlijeka i mliječnih proizvoda određena je zemljopisnim položajem i gastronomskim tradicijama kao i tržišnim i gospodarskim uvjetima (Fejzuli i sur., 2018.). Danas su najveći svjetski proizvođači mlijeka SAD-a koji je na prvom mjestu, a slijede ga Kina, Indija, Rusija, Brazil, Turska te zemlje EU (Magon i sur., 2018.). Od zemalja EU u 10 zemalja s najvećom proizvodnjom na svijetu ubrajaju se Njemačka, Francuska i Ujedinjeno Kraljevstvo. U Tabeli 1. prikazana je proizvodnja mlijeka u zemljama članicama EU u 2015., 2016. i

Tabela 1. Proizvodnja mlijeka (tone) u 2015., 2016. i 2017. u zemljama članicama EU (EFSA, 2017., 2018., 2019.).

\begin{tabular}{|c|c|c|c|}
\hline Članica EU & 2015. & 2016. & 2017. \\
\hline Njemačka & 30380817 & 31457454 & 31565955 \\
\hline Francuska & 24425788 & $n p$ & 24566911 \\
\hline Ujedinjeno Kraljevstvo & 14611308 & 14850189 & 15270310 \\
\hline Nizozemska & 12716300 & 13467400 & 14616286 \\
\hline Poljska & 12607301 & 12859447 & 12867163 \\
\hline Italija & 11071383 & 11037367 & 11159207 \\
\hline Španjolska & 6927836 & 6574721 & 6794063 \\
\hline Irska & 5900705 & 6361528 & 955974 \\
\hline Danska & 4500000 & 4613123 & 3591207 \\
\hline Belgija & 3299539 & 3464609 & 3563796 \\
\hline Švedska & 2932000 & 2921000 & 2921000 \\
\hline Češka & 2856000 & 2973000 & 2990000 \\
\hline Finska & 2288500 & 2364900 & 2359000 \\
\hline Rumunjska & 1900107 & 964612 & 915338 \\
\hline Grčka & 1892333 & 1915170 & 1897642 \\
\hline Portugal & 1847975 & 2000286 & 1935177 \\
\hline Litva & 1392429 & 1483490 & 1409456 \\
\hline Slovačka & 1262123 & 1263676 & 1252218 \\
\hline Letonija & 915000 & 972000 & 978000 \\
\hline Mađarska & 872541 & 687687 & 945230 \\
\hline Estonija & 771632 & 805165 & 783172 \\
\hline Hrvatska & 738917 & 720440 & 674200 \\
\hline Bugarska & 531304 & 569839 & 447680 \\
\hline Slovenija & 505536 & 530985 & 499965 \\
\hline Luksemburg & 287000 & 287000 & 350000 \\
\hline Cipar & 164000 & 163000 & 20000 \\
\hline Austrija & 150915 & 150915 & 146928 \\
\hline Malta & 45142 & 44274 & 45910 \\
\hline
\end{tabular}

np - nisu prikazani 
2017. godini (EFSA, 2017., 2018., 2019.). Njemačka ima najveću proizvodnju mlijeka od 31,56 milijuna tona u 2017. godini, a slijede je Francuska s 24,56 milijuna tona te Ujedinjeno Kraljevstvo s 15,27 milijuna tona mlijeka. Te zemlje imaju stalnu tendenciju porasta proizvodnje mlijeka. Porast proizvodnje mlijeka vidljiv je i u Nizozemskoj, Poljskoj, Italiji, Španjolskoj, Danskoj, Belgiji i Mađarskoj. S druge strane pad proizvodnje zabilježen je za zemlje: Danska, Švedska, Bugarska, Rumunjska, Austrija, Slovenija i Hrvatska.

U Hrvatskoj se bilježi trend pada proizvodnje mlijeka sa 738,9 tisuća tona u 2015. godini na 674,2 tisuće tona u 2017. (EFSA, 2017., 2018., 2019.). Državni zavod za statistiku RH objavio je da je u 2018. godini u RH prikupljena količina kravljeg mlijeka smanjena za 4,9\%, količina ovčjega mlijeka za 3,1 \% u odnosu na 2017. (DZS, 2019.). Jedino je za kozje mlijeko utvrđen porast proizvodnje, odnosno količine prikupljenog mlijeka za $0,9 \%$. Ovi podatci o godišnjoj proizvodnji mlijeka i mliječnih proizvoda preuzeti su od Hrvatske poljoprivredne agencije odnosno od Središnjeg laboratorija za kontrolu mlijeka (SLKM) koji analizira otkupljeno mlijeko od četrdesetak mljekara (industrijske i registrirane male mljekare) od kojih ujedno prikuplja podatke o proizvodnji.

\section{Suvremene metode u analizama veterinarskih lijekova u mlijeku}

Po svojem sastavu mlijeko je složena namirnica koja sadrži masnoće i bjelančevine, što predstavlja problem $\mathrm{u}$ postupcima pripreme uzoraka jer mogu izazvati interakcije $u$ analitičkim postupcima. Različita fizikalno-kemijska svojstava različitih veterinarskih lijekova otežavaju razvoj učinkovitog postupka ekstrakcije i pročišćavanja u postizanju zadovoljavajućih rezultata iskorištenja pojedinačnih analita u složenim vrstama uzoraka (Bogialli i Di Corcia, 2009.). Postupci pripreme uzoraka namijenjenih analizi jedne porodice antibiotika sastojala se od primjene uobičajene ekstrakcije (Robert i sur., 2013., Chen i sur., 2016.). Jedan od najprihvaćenijih pristupa je razrjeđivanje uzorka mlijeka $\mathrm{s}$ otapalom poput acetonitrila, a zatim se centrifugira i upari dobiveni organski supernatant ekstrakt (Turnipseed i sur., 2011., Zhan i sur., 2012.). Razvoj metoda za analizu više porodica lijekova najčešće objedinjuje korake taloženja proteina i zatim centrifugiranje te primjenu ekstrakcije na čvrstoj fazi (SPE, engl. solid phase exstraction) (Stolker i sur., 2008., Gaugain-Juhel i sur., 2009., Han i sur., 2015.). Do sada je SPE korišten kao najčešći i najsvestraniji način ekstrakcije $\mathrm{u}$ analizama velikog broja molekula $\mathrm{u}$ tkivima i mlijeku. U usporedbi s drugim metodama pripreme uzoraka SPE se još uvijek najviše koristi zbog značajki kao što su lako rukovanje, niski troškovi, mogućnost automatizacije i korištenje malih količina otapala. Može se smatrati višenamjenskom tehnikom, budući da se pročišćavanje i koncentracija događaju u istom koraku (Rocca i sur., 2017.).

Većina metoda koja se danas primijenjuju u pripremama uzoraka za analizu ostataka lijekova koristi velike količine otapala (ekstrakcija tekuće/ tekuće) te imaju višestruke korake pročišćavanja uzoraka (SPE) za koje je potrebno duže vrijeme analize, što $u$ konačnici daje visoke troškove. Stoga se nastoje razviti metode pripreme uzoraka koje su jednostavne, jeftine i vremenski manje traju, a istovremeno omogućuju analizu različitih porodica lijekova kao i ostalih tvari, kao što su na primjer zabranjene tvari, beta-agonisti i nitroimidazoli (Robert i sur., 2013.) ili pesticidi (Imamoglu i Olgun, 2016.). Danas se sve češće primijenjuje nova metoda pripreme QuEChERS (engl. 
Quick Easy Cheap Effective Rugged Safe) koja se bazira na primjeni kombinacija različitih soli. Njezina izvorna primjena je bila namijenjena pripremi uzoraka za analizu pesticida (Anastassiades i sur., 2003.), zatim započinje i njena primjena $\mathrm{u}$ pripremi uzoraka za analizu veterinarskih lijekova u različitim vrstama uzoraka (Stubbings i Bigwood, 2009., Kaufmann i sur., 2014.). Nedostatak ovog postupka je nemogućnost postizanja zadovoljavajućih iskorištenja za polarne

Tabela 2. Suvremene analitičke metode koje omogućuju analizu ostataka različitih porodica antibiotika i drugih veterinarskih lijekova u mlijeku.

Skupina farmakološki aktivnih
tvari

amfenikoli, antihelmintici, linkozamidi, makrolidi, kinoloni, sulfonamidi, kokcidiostatici,

nesteroidni protuupalni lijekovi, nitrofurani, nitroimidazoli, sedativi, peptidni lijekovi

beta laktami: penicilini i cefalosporini

amfenikoli, avermektini, benzimidazoli, linkozamidi, makrolidi, kinoloni, sulfonamidi, kokcidiostatici, nesteroidni protuupalni lijekovi, salicilanilidi, sedativi

fluorokinoloni, ionofori, makrolidi, nitroimidazol, nesteroidni protuupalni lijekovi, $\beta$-laktami, penicilini, fenikoli, sulfonamidi, tetraciklini

cefalosporini, penicilini kinoloni, tetraciklini, makrolidi, sulfonamidi, i dr.

kinoloni, makrolidi, beta laktami, nitroimidazoli, sulfonamidi, linkomicini, kloramfenikoli, kinoksalini, tetraciklini, polipeptidi

kinoloni, tetraciklini, makrolidi, sulfonamidi

kinoloni, tetraciklini, makrolidi, sulfonamidi, penicilini

amfenikoli, cefalosporini, penicilini kinoloni, tetraciklini, makrolidi, sulfonamidi, linkozamini, i dr.

beta laktami, kinoloni, tetraciklini, makrolidi, sulfonamidi, linkozamini amfenikoli, beta-laktami, makrolidi, pirimidini, kinoloni, sulfonamidi, tetraciklini, beta-agonisti, kortikosteroidi, kokcidiostatici, nitroimidazoli, nesteroidni protuupalni lijekovi, sedativi

\section{Postupak pripreme \\ Instrument Referenca}

$\begin{array}{lll}\text { ekstrakcija tekuće/ } & \text { UPLC- } & \text { Amelin i sur., } \\ \text { tekuće } & \text { Q-ToF-MS } & 2018 .\end{array}$

QuEChERS

LC-MS/MS

Bessaire i sur., 2018.

\begin{tabular}{l|l} 
QUEChERS LC-MS/MS & $\begin{array}{l}\text { Desmarchelier } \\
\text { sur., } 2018 .\end{array}$
\end{tabular}

ekstrakcija na čvrstoj UHPLC/ESI Wang i sur., fazi (SPE)

Q-Orbitrap

2018.

ekstrakcija na čvrstoj UPLC-

fazi (SPE)

Q-ToF-MS

Jank i sur., 2017

ekstrakcija tekuće/

tekuće potpomognuta

ultrazvukom i

LC-MS/MS Chen i sur., 2016.

ekstrakcija na čvrstoj fazi (SPE)

\begin{tabular}{l|l|l}
$\begin{array}{l}\text { ekstrakcija tekuće/ } \\
\text { tekuće }\end{array}$ & LC-MS/MS & $\begin{array}{l}\text { Imamoglu i } \\
\text { Olgun, 2016. }\end{array}$ \\
$\begin{array}{l}\text { ekstrakcija na čvrstoj } \\
\text { fazi (SPE) }\end{array}$ & LC-MS/MS & Zhu i sur., 2016. \\
\hline $\begin{array}{l}\text { ekstrakcija na čvrstoj } \\
\text { fazi (SPE) }\end{array}$ & $\begin{array}{l}\text { UPLC- } \\
\text { Q-ToF-MS }\end{array}$ & $\begin{array}{l}\text { Daseneki i sur., } \\
2015 .\end{array}$ \\
\hline $\begin{array}{l}\text { ekstrakcija na čvrstoj } \\
\text { fazi (SPE) }\end{array}$ & $\begin{array}{l}\text { UPLC- } \\
\text { MS/MS }\end{array}$ & Han i sur., 2015.
\end{tabular}

ekstrakcija tekuće/ tekuće

LC-MS/MS

Robert i sur., 2013. 
lijekove kao što su tetraciklini, kinoloni i penicilini (Kaufmann i sur., 2014.). Danas se radi na optimizaciji ovog postupka $u$ svrhu postizanja analize što većeg broja analita s prihvatljivim iskorištenjima (Desmarchelier i sur., 2018.).

Tehnologija koja se danas smatra zlatnim standardom $u$ razvoju $t z v$. multimetoda (Tabela 2) koje omogućuju kvantifikaciju stotine aktivnih tvari je masena spektrometrija. Pri tome je tekućinska kromatografija povezana s tandemskom masenom spektrometrijom (LC-MS) najprimjenjivanija tehnika (Desmarchelier i sur., 2018.). Najprimjenjivaniji spektrometar masa je trostruki kvadrupol (QqQ) kojeg karakterizira mogućnost postizanja dobrih rezultata kvantifikacije analita te identificiranje ciljanih spojeva uz visoku selektivnost i specifičnost (Kaufmann i sur., 2011.), a koristi se i tekućinska kromatografija povezana $\mathrm{s}$ masenom spektrometrijom visoke razlučivosti (LCHRMS) primjenom spektrometara kao što su: spektrometar vremena leta TOF (engl. time-of-flight) (Wang i Leung, 2012., Staub Spörri i sur., 2014., Daseneki i sur., 2015.) ili Orbitrap (Gómez-Pérez i sur., 2012., Wang i sur., 2018.).

Metode koje primijenjuju LC-MS/MS tehnologiju danas $\mathrm{u}$ uzorcima mlijeka omogućuju identifikaciju 88 (Zhu i sur., 2016.), 105 (Desmarchelier i sur., 2018.), 115 (Dasenaki i Thomaidis, 2015.), 120 (Chen i sur., 2016.), 143 (Daseneki i sur., 2015.), 150 (Amelin i sur., 2018.) ili čak 160 farmakološki aktivnih tvari (Robert i sur., 2013.).

\section{Kontrola ostatka farmakološki aktivnih tvari u mlijeku u EU}

U kontroli ostataka veterinarskih lijekova izazov za kontrolna tijela EU te prehrambenu industriju je upravljanje $s$ tri čimbenika, odnosno analiza velikog broja kemijskih spojeva (više stotina), raspon vrsta hrane koju treba nadgledati (meso, mast, mlijeko, jaja, riba, plodovi mora, med) te legislativa koja definira zakonske okvire njihove zdravstvene ispravnosti (Bessaire i sur., 2018.).

U svrhu osiguranja sigurnosti potrošača, a na temelju studija procjena rizika EU je definirala najveće dopuštene količine ostataka (NDK) farmakološki aktivnih tvari u hrani životinjskog podrijetla uredbom Komisije (EZ) br. 37/2010 (EC, 2010.). Ovisno o vrsti veterinarskih lijekova koji su dopušteni za primjenu u mliječnih goveda NDK vrijednosti $\mathrm{u}$ mlijeku kreću se od na primjer 0,1 $\mu \mathrm{g} / \mathrm{kg}$ za diklofenak, $4 \mu \mathrm{g} /$ $\mathrm{kg}$ za ampicilin do na primjer $100 \mu \mathrm{g} / \mathrm{kg}$ za tetraciklin ili $200 \mu \mathrm{g} / \mathrm{kg}$ za spiramicin. Kada lijek nije dopušten za primjenu $u$ govedima, odnosno ostalim preživačima koji proizvode mlijeko, vrijednosti ustvrđene tvari $\mathrm{u}$ mlijeku ne smiju biti iznad graničnih koncentracija analita koju neka metoda može postići. Ovi parametri određuju se validacijskim postupcima definiranih Odlukom Komisije 2002/657/ EZ (EC, 2002.a).

Direktiva Vijeća 96/23/EZ definira kontrolu farmakološki aktivnih tvari članicama EU koje su obvezne provoditi njihovu kontrolu provođenjem nacionalnih planova praćenja ostataka lijekova (NPPR) u životinjama koje se koriste za proizvodnju hrane odnosno mlijeku (EC, 1996.). Broj analiza na razini države određuje se prema proizvodnji mlijeka. Prema Direktivi, skupinu B, koja objedinjuje veterinarske lijekove, čine podskupine B1 antibakterijske tvari, uključujući sulfonamide i kinolone i B2 ostali veterinarski lijekovi koja je podijeljena na: B2a anthelmintici, B2b kokcidiostatici, B2c karbamati i piretroidi, B2d sedativi, B2e nesteroidni protuupalni lijekovi, B2f ostale farmakološki aktivne tvari. Ova Direktiva je zamijenjena Uredbom 2017/625 o službenim kontrolama i drugim službenim aktivnostima kojima se osigurava primjena propisa o hrani i hrani za 
životinje, pravila o zdravlju i dobrobiti životinja, zdravlju bilja i sredstvima za zaštitu bilja (EC, 2017.). Njena primjena započinje u prosincu 2019., no još do prosinca 2022. ostaju na snazi odredbe Direktive 96/23/EZ.

Europska agencija za sigurnost hrane (EFSA) obvezna je prikupiti podatke kontrole farmakološki aktivnih tvari u mlijeku svih članica EU analiziranih u okviru NPPR prema Direktivi Vijeća 96/23/EZ te svake godine prilaže zajedničko izvješće. Izvještaj obuhvaća ukupnu proizvodnju mlijeka, broj analiziranih uzoraka te broj nesukladnih rezultata po pojedinoj analiziranoj tvari te ukupni broj nesukladnih rezultata pronađenih u mlijeku svih članica EU.

U Tabeli 3 prikazani su nesukladnih rezultati kontrole farmakološki aktivnih tvari u mlijeku ustvrđenih u NPPR članica EU u 2015., 2016. i 2017. godini (EFSA, 2017., 2018., 2019.). U okviru planova država članica EU u te tri godine broj analiziranih uzoraka mlijeka kretao se između 22667 i 25364 uzoraka. Ukupan postotak nesukladnih rezultata za farmakološki aktivne tvari $\mathrm{u}$ mlijeku za te tri godine iznosio je $0,115 \%, 0,128 \%$ i $0,304 \%$. U 2017. godini ustvrđen je najveći broj nesukladnih rezultata za skupinu antibakterijskih tvari (B1) i nesteroidne protuupalne lijekove (B2e). Ustvrđeni su i nesukladni rezultati i za skupinu antihelmintika koji su na ukupni broj nesukladnih iznosili u te tri godine $25 \%, 14,3 \%$ i $15,1 \%$. Nisu ustvrđeni nesukladni rezultati u skupinama kokcidiostatika, karbamata i piretroida, sedativa i ostalih farmakološki aktivnih tvari.

Tabela 3. Broj nesuklađenih uzoraka ustvrđenih u mlijeku za farmakološki aktivnih tvari članica EU u okviru nacionalnih planova praćenja rezidua u 2015., 2016. i 2017. godini (EFSA, 2017., 2018., 2019.).

\begin{tabular}{|c|c|c|c|c|c|c|c|}
\hline \multirow[b]{2}{*}{$\begin{array}{l}\text { Oznaka } \\
\text { skupine }\end{array}$} & \multirow[b]{2}{*}{$\begin{array}{l}\text { Farmakološki } \\
\text { aktivne tvari }\end{array}$} & \multicolumn{2}{|c|}{2015.} & \multicolumn{2}{|c|}{2016.} & \multicolumn{2}{|c|}{2017.} \\
\hline & & 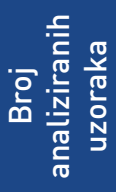 & 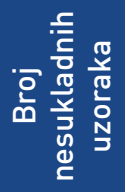 & 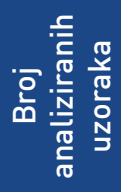 & 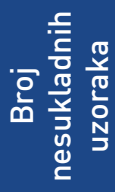 & 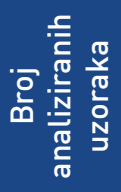 & 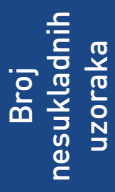 \\
\hline B1 & $\begin{array}{l}\text { Antibakterijske } \\
\text { tvari, uključujući } \\
\text { sulfonamide, } \\
\text { kinolone }\end{array}$ & 13168 & 17 & 11929 & 15 & 10634 & 24 \\
\hline B2a & Anthelmintici & 5458 & 5 & 5227 & 3 & 6635 & 11 \\
\hline $\mathrm{B} 2 \mathrm{~b}$ & Kokcidiostatici & 102 & 0 & 494 & 0 & 1272 & 0 \\
\hline B2C & $\begin{array}{l}\text { Karbamati i } \\
\text { piretroidi }\end{array}$ & 352 & 0 & 275 & 0 & 1778 & 0 \\
\hline B2d & Sedativi & 55 & 0 & 56 & 0 & 82 & 0 \\
\hline B2e & $\begin{array}{l}\text { Nesteroidni } \\
\text { protuupalni lijekovi }\end{array}$ & 3545 & 5 & 3810 & 11 & 4474 & 42 \\
\hline$B 2 f$ & $\begin{array}{l}\text { Ostale } \\
\text { farmakološki } \\
\text { aktivne tvari }\end{array}$ & 838 & 0 & 876 & 0 & 489 & 0 \\
\hline & UKUPNO & 23518 & 27 & 22667 & 29 & 25364 & 77 \\
\hline
\end{tabular}


Tabela 4. Nesuklađeni rezultati farmakološki aktivnih tvari članica EU u mlijeku u okviru nacionalnih planova praćenja rezidua u 2015., 2016. i 2017. godini (EFSA, 2017., 2018., 2019.).

\begin{tabular}{|c|c|c|c|c|c|}
\hline \multirow{2}{*}{$\begin{array}{l}\text { Skupina farmakološki } \\
\text { aktivnih tvari }\end{array}$} & \multirow{2}{*}{ Aktivna tvar } & \multirow{2}{*}{$\begin{array}{c}\text { NDK } \\
(\mu g / k g)\end{array}$} & \multicolumn{3}{|c|}{ Broj nesukladnih rezultata } \\
\hline & & & 2015. & 2016. & 2017. \\
\hline \multirow{23}{*}{$\begin{array}{l}\text { Antibakterijske tvari, } \\
\text { uključujući sulfonamide, } \\
\text { kinolone }\end{array}$} & Amoksicilin & 4 & 2 & 1 & 2 \\
\hline & Ampicilin & 4 & 2 & 1 & \\
\hline & Benzilpenicilin & 4 & 2 & 2 & 3 \\
\hline & Cefaleksin & 100 & 1 & & \\
\hline & Cefkvinom & 20 & 1 & & \\
\hline & Cefalonij & 20 & & 1 & 1 \\
\hline & Cefazolin & 50 & & 1 & \\
\hline & Kloksacilin & 30 & 3 & 1 & 3 \\
\hline & Danofloksacin & 30 & & 1 & \\
\hline & Ciproflokskacin & 100 & & & 1 \\
\hline & Enrofloksacin & 100 & 1 & & \\
\hline & Gentamicin & 100 & & 2 & \\
\hline & Tilmikozin & 50 & 2 & 2 & 1 \\
\hline & Linkomicin & 150 & & 1 & \\
\hline & Kanamicin & 150 & 1 & & \\
\hline & Spiramicin & 200 & 1 & & \\
\hline & Tetraciklin & 100 & 1 & 2 & 1 \\
\hline & Doksiciklin & 100 & & & 2 \\
\hline & Oksitetraciklin & 100 & & & 1 \\
\hline & Trimetoprim & 50 & & & 1 \\
\hline & Tulatromicin & nd & & & 1 \\
\hline & Florfenikol & nd & & & 7 \\
\hline & \multicolumn{2}{|l|}{ Ukupno } & 17 & 15 & 24 \\
\hline \multirow{11}{*}{ Anthelmintici } & Albendazol & 100 & 1 & & \\
\hline & Triklabendazol & 10 & 1 & 1 & \\
\hline & $\begin{array}{l}\text { Triklabendazol- } \\
\text { sulfon }\end{array}$ & 10 & & & 1 \\
\hline & Ketotriklabendazol & 10 & & & 1 \\
\hline & Oksfendazolsulfon & 10 & & & 1 \\
\hline & Klosantel & 45 & 1 & & 1 \\
\hline & Klorsulon & 16 & & & 1 \\
\hline & Nitroksinil & 20 & & & 1 \\
\hline & Ivermektin & nd & 2 & 2 & 4 \\
\hline & Levamizol & nd & & & 1 \\
\hline & \multicolumn{2}{|l|}{ Ukupno } & 5 & 3 & 11 \\
\hline \multirow{3}{*}{$\begin{array}{l}\text { Nesteroidni protuupalni } \\
\text { lijekovi }\end{array}$} & Diklofenak & 0,1 & 5 & 10 & 4 \\
\hline & Salicilna kiselina & 9 & & 1 & 38 \\
\hline & Ukupno & & 5 & 11 & 42 \\
\hline UKUPNO & & & 27 & 29 & 77 \\
\hline
\end{tabular}

nd - nije dopušten 
U Tabeli 4 prikazani su nesukladni rezultati pojedinih farmakološki aktivnih tvari utvrđenih u okviru NPPR članica EU (EFSA, 2017., 2018., 2019.). U skupini antibakterijskih tvari (B1) najveći broj nesukladnih tvari iznad NDK ustvrđen je u 2017. U skupini antibakterijskih tvari ustvrđeno je 27 nesukladnih rezultata beta-laktamskih antibiotika što čini ukupno 48,2 \% nesukladnih tvari gledajući ukupno sve tri godine. U 2017. godini najveći broj nesukladnih se odnosi na skupinu nesteroidnih protuupalnih lijekova $(54,5 \%)$, odnosno u toj skupini lijekova $90,5 \%$ nesuklađenih se odnosi na nesuklađene rezultate salicilne kiseline.

U okviru NPRR u Hrvatskoj su u 2017. godini ustvrđeni nesukladni rezultati $\mathrm{u}$ po jednom mlijeku za amoksicilin, kloksacilin, levamizol i diklofenak te 35 nesukladnih rezultata za salicilnu kiselinu. Primjera radi za iste tvari $u$ 2017. povišene vrijednosti ustvrđene su za amoksicilin i kloksacilin u po jednom mlijeku iz Italije, te $u$ po jednom mlijeku za diklofenak u Austriji, Estoniji i Njemačkoj. Povišene vrijednosti salicilne kiseline utvrđene su u jednom mlijeku iz Danske te $\mathrm{u}$ dva iz Nizozemske (EFSA, 2019.).

Članice EU također prijavljuju nesuklađene rezultate farmakološki aktivnih tvari u RASFF, centralni sustav brzog uzbunjivanja za hranu i hranu za životinje (engl. Rapid Alert System for Food and Feed) (EC, 2002.b). U razdoblju od 2009. do 2019. godine prijavljen je mali broj nesukladnih uzoraka u mlijeku i mliječnim proizvodima. U 2009. godini u Italiji su ustvrđene povišene vrijednosti penicilinskih antibiotika $u$ mlijeku podrijetlom iz Austrije. U 2016. godini u Litvi ustvrđene su koncentracije tetraciklina od $312 \mu \mathrm{g} / \mathrm{kg}$ u kravljem siru podrijetlom iz Rusije. U 2017. godini su u Italiji ustvrđene povišene koncentracije kloksacilina $(1685 \mu \mathrm{g} / \mathrm{kg}) \mathrm{u}$ kozjem siru podrijetlom iz Italije. U kravljem siru podrijetlom iz Bosne i Hercegovine su iste godine u Hrvatskoj ustvrđene povišene vrijednosti salicilne kiseline $(114,8 \mu \mathrm{g} / \mathrm{kg})$ (RASFF, 2009. - 2019.).

Istraživanja u kojima su uzorci mlijeka analizirani na prisutnost farmakološki aktivnih tvari pokazuju male postotke nesuklađenih uzoraka. Analizom 500 uzoraka mlijeka u SAD ustvrđen je samo jedan uzorak sa koncentracijom fluniksina (nesteroidni protuupalni lijek) većom od dopuštene granice od $2 \mu \mathrm{g} / \mathrm{kg}$ (Kissell i sur., 2013.). U mlijeku iz Turske ustvrđeni su ostatci sulfadiazina $u$ dva uzorka s koncentracijama između 75 i 125 $\mu \mathrm{g} / \mathrm{L}$, odnosno koncentracije tetraciklina između 15 i $100 \mu \mathrm{g} / \mathrm{L} \mathrm{u} 4$ uzorka mlijeka (Imamoglu i Olgun, 2016.). Istraživanja provedena u SAD u mlijeku pokazala su svega $1,15 \%$ nesuklađenih rezultata veterinarskih lijekova (11 pozitivnih uzoraka na ukupno 953 analiziranih) (FDA, 2015.). U 247 uzorka mlijeka iz Brazila koji su analizirani na ostatke betalaktama, povišene vrijednosti određene su za kloksacilin i cefapirin (Jank i sur., 2015.).

Provedeno je niz istraživanja $\mathrm{u} \mathrm{Hr}$ vatskoj. U istraživanju koncentracija kinolona flumekina u mlijeku podrijetlom iz Hrvatske primjenom ELISA metode nisu ustvrđene koncentracije iznad NDK vrijednosti od $50 \mu \mathrm{g} / \mathrm{kg}$ (Bilandžić i sur., 2015.). Također, istraživanje koncentracija levamizola primjenom LC-MS/MS u mlijeku pokazalo je da su sve koncentracije ispod granice kvantifikacije metode od 0,22 $\mu \mathrm{g} / \mathrm{kg}$ (Bilandžić i sur., 2016.). Analiza 18 spojeva benzimidazola primjenom LC-MS/MS u mlijeku iz Hrvatske u 2016. godini također je pokazala da su vrijednosti svih spojeva ispod granica kvantifikacije metode (Denžić Lugomer i sur., 2017.). Tijekom 2017. godine analizirano je ukupno 50 uzoraka sirovog kravljeg mlijeka na ostatke aminoglikozida. U jednom uzorku mlijeka određene su koncentracije dihidrostreptomicina iznad NDK, odnosno $300 \mu \mathrm{g} /$ kg (Bilandžić i sur., 2018.). 
Iako su ustvrđeni mali postotci nesukladnih rezultata farmakološki aktivnih tvari u kontrolama službenih uzoraka mlijeka na nivou EU ili $\mathrm{u}$ različitim istraživanjima, teži se razvoju metoda koje imaju visoku pouzdanost i selektivnost te omogućuju analizu velikog broja farmakološki aktivnih tvari. U svijetu je tendencija razvoja multimetoda koje omogućuju identifikaciju i kvantifikaciju više desetaka ili više od 100 tvari različitih skupina tvari od veterinarskih lijekova, zabranjenih tvari do kontaminanata, a sve u svrhu postizanja kriterija što bolje zaštite zdravlja potrošača.

\section{Literatura}

1. AMELIN, V. G., N. M. FEDINA, I. V. PODKOLZIN and A. I. KOROTKOV (2018): Rapid Screening and determination of residual veterinary drugs in milk by ultrahigh performance liquid chromatographyhigh-resolution quadrupole time-of-flight mass spectrometry. J. Anal. Chem. 73, 576-585.

2. ANASTASSIADES, M., S. J. LEHOTAY, D. STAJNBAHER and F. J. SCHENCK (2003): Fast and easy multiresidue method employing acetonitrile extraction/partitioning and "dispersive solid-phase extraction" for the determination of pesticide residues in produce. J AOAC Int. 86, 412-431.

3. BESSAIRE, T., C. MUJAHID, A. BECK, A. TARRES, M.-C. SAVOY, P.-M. WOO, P. MOTTIER and A. DESMARCHELIER (2018): Screening of 23 $\beta$-lactams in foodstuffs by LC-MS/MS using an alkaline QuEChERS-like extraction. Food Addit. Contam. A 35, 661-673.

4. BILANDŽIĆ, N., B. KOS, J. ŠUŠKOVIĆ, M. VREBAC, B. SOLOMUN KOLANOVIĆ i I. VARGA (2015): Kontrola rezidua flumekina u uzorcima mlijeka. Vet. stn. 46, 83-88.

5. BILANDŽIĆ, N., Đ. BOŽIĆ LUBURIĆ, B. SOLOMUN KOLANOVIĆ, I. VARENINA and I. VARGA (2016): Control of levamisole residues in milk using a validated liquid chromatographytandem mass spectrometry method. Mljekarstvo 66, 146-153.

6. BILANDŽIĆ, N., L., FEJZULI, B. SOLOMUN KOLANOVIĆ, I. VARENINA, I. VARGA, Đ. BOŽIĆ LUBURIĆ, B. KOS i J. ŠUŠKOVIĆ (2018): Ostaci aminoglikozida u sirovom mlijeku. 43 Hrvatski simpozij mljekarskih stručnjaka s međunarodnim sudjelovanjem (Lovran 7.-10. studenog 2018.). Knjiga sažetaka, Zagreb: Hrvatska mljekarska udruga (66-67).
7. BOGIALLI, S. and A. DI CORCIA (2009): Recent applications of liquid chromatography-mass spectrometry to residue analysis of antimicrobials in food of animal origin. Anal. Bioanal. Chem. 395, 947-966.

8. BOOTH, N. H. (1998): Toxicology of drug and chemical residues. Veterinary Pharmacology and Therapeutics. Ames Iowa: Iowa State University Press (1149-1205).

9. BOURIN, M. and F. CLÉNET (2014): Regulation of the Risk of Exposure to Antibiotics in Milk. Pharmaceut Reg Affairs 3, e128.

10. CHEN, D., J. YU, Y. TAO, Y. PAN, S. XIE, L. HUANG, D. PENG, X. WANG, Y. WANG, Z. LIU and Z. YUAN (2016): Qualitative screening of veterinary anti-microbial agents in tissues, milk, and eggs of food-producing animals using liquid chromatography coupled with tandem mass spectrometry. J. Chromatogr. B 1017-1018, 82-88.

11. DASENAKI, M. E. and N. S. THOMAIDIS (2015): Multi-residue determination of 115 veterinary drugs and pharmaceutical residues in milk powder, butter, fish tissue and eggs using liquid chromatography-tandem mass spectrometry. Anal. Chim. Acta. 880, 103-121.

12. DASENAKI, M. E., A. A. BLETSOU, G A. KOULIS and N. S. THOMAIDIS (2015): Qualitative multiresidue screening method for 143 veterinary drugs and pharmaceuticals in milk and fish tissue using liquid chromatography quadrupole-time-offlight mass spectrometry. J. Agric. Food Chem. 63, 4493-4508.

13. DENŽIĆ LUGOMER, M., D. PAVLIČEK, N. BILANDŽIĆ, M. KIŠ and D. MAJNARIĆ (2017): Determination of benzimidazole residues and their metabolites in raw milk in Croatia using high performance liquid chromatography-diode array detection. Mljekarstvo 67, 231-238.

14. DESMARCHELIER, A., K. FAN, M. M. TIEN, M.C. SAVOY, A. TARRES, D. FUGER, A. GOYON, T. BESSAIRE and P. MOTTIER (2018): Determination of 105 antibiotic, antiinflammatory, antiparasitic agents and tranquilizers by LC-MS/MS based on an acidic QuEChERS-like extraction. Food Addit. Contam. A 35, 646-660.

15. DZS (2019): Proizvodnja mlijeka i mliječnih proizvodau 2018. Državnizavod zastatistiku, godina LVI, broj 1.1.25.. Dostupno na: https://www.dzs.hr/ Hrv_Eng/publication/2019/01-01-25_01_2019.htm. Pristupnjeno 6.11.2019.

16. EC (1996): Council Directive 96/23/EC of 29 of April 1996 on measures to monitor certain substances and residues thereof in live animals and animal products and repealing Directives 85/358/EEC and 86/469/EEC and Decisions 89/187/EEC and 91/664/ EEC. Off. J. Eur. Commun. L 125, 10-32.

17. EC (2002a): Commission Decision 2002/657/EC of 12 August 2002 implementing Council Directive 
96/23/EC concerning the performance of analytical methods and the interpretation Off. J. Eur. Commun. L 221, 8-28.

18. EC (2002b): Regulation (EC) No 178/2002 of the European parliament and of the council of 28 January 2002 laying down the general principles and requirements of food law, establishing the European Food Safety Authority and laying down procedures in matters of food safet. Off. J. Eur. Commun. L31, 1-24.

19. EC (2010): Council Regulation 37/2010/EU of 22 December 2009 on pharmacologically active substances and their classification regarding maximum residue limits in foodstuffs of animal origin. Off. J. Eur. Commun. L15, 1-72.

20. EC (2017): Regulation (EU) 2017/625 of the European Parliament and of the Council of 15 March 2017on official controls and other official activities performed to ensure the application of food and feed law, rules on animal health and welfare, plant health and plant protection products. Off. J. Eur. Commun. L 95, 1-142.

21. ECONOMOU, V. and P. GOUSIA (2015): Agriculture and food animals as a source of antimicrobial-resistant bacteria. Infect. Drug Resist. 8, 49-61.

22. EFSA (2017): Report for 2015 on the results from the monitoring of veterinary medicinal product residues and other substances in live animals and animal product. EFSA Supporting publication 2017: EN-1150.

23. EFSA (2018): Report for 2016 on the results from the monitoring of veterinary medicinal product residues and other substances in live animals and animal product. EFSA Supporting publication 2018: EN-1358.

24. EFSA (2019): Report for 2017 on the results from the monitoring of veterinary medicinal product residues and other substances in live animals and animal product. EFSA Supporting publication 2019: EN-1579.

25. FDA (2015): Milk drug residue sampling survey. Food and Drug Administration Department of Health and Human Services. March 2015.

26. FEJZULI, L., B. SOLOMUN KOLANOVIĆ, J. ŠUŠKOVIĆ, B. KOS i N. BILANDŽIĆ (2018): Aminoglikozidini antibiotici - primjena u veterinarstvu i kontrola u hrani životinjskog podrijetla. Hrvat. čas. prehrambenu tehnol. biotehnol. nutricon. 13, 95-106.

27. FISHER, W. J., B. SCHILTER, A. M. TRITSCHER and R. H. STADLER (2011): Environmental contaminants. In: Fuquay, J. W., Fox, P. F., McSweeney, P. L. H.: Encyclopedia of dairy science. Elsevier, London/New York (898-905).

28. GAUGAIN-JUHEL, M., B. DEL'EPINE, S GAUTIER, M.-P. FOURMOND, V. GAUDIN, D. HURTAUD-PESSEL, E. VERDON and P. SANDERS (2009): Validation of a liquid chromatography- tandem mass spectrometry screening method to monitor 58 antibiotics in milk: a qualitative approach. Food Addit. Contam. A 26, 1459-1471.

29. GETANEH, A. M., S. A. MEKONNEN and H. HOGEVEEN (2017): Stochastic bio-economic modeling of mastitis in Ethiopian dairy farms. Prev. Vet. Med. 138, 94-103.

30. GÓMEZ-PÉREZ, M. L., P. PLAZA-BOLAÑOS, R. ROMERO-GONZÁLEZ, J. L. MARTÍNEZVIDAL and A. GARRIDO-FRENICH (2012): Comprehensive qualitative and quantitative determination of pesticides and veterinary drugs in honey using liquid chromatography - Orbitrap high resolution mass spectrometry. J. Chromatogr. A $1248,130-138$.

31. HALASA, T., K. HUIJPS, O. ØSTERÅS and H. HOGEVEEN (2007): Economic effects of bovine mastitis and mastitis management: a review. Vet $Q$. 29, 18-31.

32. HAN, R. W., N. ZHENG, Z. N. YU, J. WANG, W. M. XU, W. Y. QU, S. L. LI, Y. D. ZHANG and J. Q. WANG (2015): Simultaneous determination of 38 veterinary antibiotic residues in raw milk by UPLC-MS/MS. Food Chem. 181, 119-126.

33. HASSAN, M.M, K. B. AMIN, M.AHADUZZAMAN, M. ALAM, M. S, A. FARUK and I. UDDIN (2014): Antimicrobial resistance pattern against E. coli and salmonella in layer poultry. Res. J. Vet. Pract. 2, 30-35.

34. IMAMOGLU, H. and E. O. OLGUN (2016): Analysis of Veterinary Drug and Pesticide Residues Using the Ethyl Acetate Multiclass/Multiresidue Method in Milk by Liquid Chromatography-Tandem Mass Spectrometry. J. Anal. Methods Chem. 2016, 17 pages.

35. JANK, L., M. T. MARTINS, J. B. ARSAND, R. B. HOFF, F. BARRETO and T. M. PIZZOLATO (2015): High-throughput method for the determination of residues of $\beta$-lactam antibiotics in bovine milk by LC-MS/MS. Food Addit. Contam. 32, 1992-2001.

36. JANK, L., M. T. MARTINS, J. B. ARSAND, T. M. C. MOTTA, T. C. FEIJÓ, T. DOSSANTOS CASTILHOS, R. B. HOFF, F. BARRETO and T. M. PIZZOLATO (2017): Liquid chromatography-tandem mass spectrometry multiclass method for 46 antibiotics residues in milk and meat: development and validation. Food Anal. Met. 10, 2152-2164.

37. KAUFMANN, A., P. BUTCHER, K. MADEN, S. WALKER and M. WIDMER (2011): Development of an improved high resolution mass spectrometry based multi-residue method for veterinary drugs in various food matrices. Anal. Chim. Acta 700, 86-94.

38. KAUFMANN, A., P. BUTCHER, K. MADEN, S. WALKER and M. WIDMER (2014): Multi-residue quantification of veterinary drugs in milk with a novel extraction and cleanup technique: salting out supported liquid extraction (SOSLE). Anal. Chim. Acta 820, 56-68.

39. KISSELL, L.W., R.E. BAYNES, J. E. RIVIERE and G. W. SMITH (2013): Occurrence of flunixin residues 
in bovine milk samples from the USA. Food Addit. Contam. A 30, 1513-1516.

40. KUANG, Y., H. JIA, K. MIYANAGA and Y. TANJI (2009): Effect of milk on antibacterial activity of tetracycline against Escherichia coli and Staphylococcus aureus isolated from bovine mastitis. Appl. Microbiol. Biotechnol. 84, 135-142.

41. LESLIE, K. E. and C. S. PETERSSON-WOLFE (2012): Assessment and management of pain in dairy cows with clinical mastitis. Vet. Clin. N. Am. Food Anim. Pract. 28, 289-305.

42. MAGON, T., R. DA SILVEIRA, M. B. GALUCH, E. P. FAGAN, A. F. D. FEITOZA, S. V. PALOMBINI, O. O. SANTOS and J. V. VISENTAINER (2018): Simultaneous determination of four antibiotics in raw milk by UPLC-MS/MS using protein precipitation as sample preparation: development, validation, and application in real samples. J. Braz. Chem. Soc. 29, 2441-2448.

43. MISHRA, A., S. K. SINGH, Y. P. SAHNI, T. K. MANDAL, S. CHOPRA, V. N. GAUTAM and S. R. QURESHI (2011): HPLC determination of cloxacillin residue in milk and effect of pasteurization. Res. J. Pharm. Bio. Chem. Sci. 3, 11-16.

44. RASFF (2009-2019): Rapid alert system for food and feed (RASFF). Dostupno na: https://webgate.ec.europa.eu/rasff-window/ portal/?event $=$ SearchForm \&cleanSearch $=1$. Pristupljeno 28.10.2019.

45. ROBERT, C., N. GILLARD, P.-Y. BRASSEUR, G. PIERRET, N. RALET, M. DUBOIS and P. DELAHAUT (2013): Rapid multi-residue and multi-class qualitative screening for veterinary drugs in foods of animal origin by UHPLC-MS/MS. Food Addit. Contam. A 30, 443-457.

46. ROCCA, L. M., A. GENTILI, V. PÉREZFERNÁNDEZ and P. TOMAI (2017): Veterinary drugs residues: a review of the latest analytical research on sample preparation and LCMS based methods. Food Addit. Contam. A 34, 766-784.

47. SONG, W. and M. GUO (2014): Applied manure and nutrient chemistry for sustainable agriculture and environment. Chapter 2, Residual veterinary pharmaceuticals in animal manures and their environmental behaviors in Soils. Dordrecht: Springer Science+Business Media. Pp. 23-52.

48. STAUB SPÖRRI, A., P. JAN, E. COGNARD, D. ORTELLI and P. EDDER (2014): Comprehensive screening of veterinary drugs in honey by ultrahigh-performance liquid chromatography coupled to mass spectrometry. Food Addit. Contam. A 31, 806-816.

49. STOLKER, A. A. M., P. RUTGERS, E. OOSTERINK, J. J. P. LASAROMS, R. J. B. PETERS, J. A. VAN RHIJN and M. W. F. NIELEN (2008): Comprehensive screening and quantification of veterinary drugs in milk using UPLC-ToF-MS. Anal. Bioanal. Chem. 391, 2309-2322.

50. STUBBINGS, G. and T. BIGWOOD (2009): The development and validation of a multiclass liquid chromatography tandem mass spectrometry (LC-MS/MS) procedure for the determination of veterinary drug residues in animal tissue using a QuEChERS (Quick, Easy, Cheap, Effective, Rugged and Safe) approach. Anal. Chim. Acta. 637, 68-78.

51. TURNIPSEED, S. B., J. M. STOREY, S. B. CLARK and K. E. MILLER (2011): Analysis of veterinary drugs and metabolites in milk using quadrupole time-offlight liquid chromatography-mass spectrometry. J. Agric. Food Chem. 59, 7569-7581.

52. VAN BOECKEL, T. P., C. BROWER, M. GILBERT, B. T. GRENFELL, S. A. LEVIN, T. P. ROBINSON, A. TEILLANT and R. LAXMINARAYAN (2015): Global trends in antimicrobial use in food animals. Proc. Natl. Acad. Sci. USA 112, 5649-5654.

53. WANG, J. and D. LEUNG (2012): The challenges of developing a generic extraction procedure to analyze multi-class veterinary drug residues in milk and honey using ultra-high pressure liquid chromatography quadrupole time-of-flight mass spectrometry. Drug Test. Anal. 4, 103-111.

54. WANG, J., D. LEUNG, W. CHOW, J. CHANG and J. W. WONG (2018): Target screening of 105 veterinary drug residues in milk using UHPLC/ ESI Q-Orbitrap multiplexing data independent acquisition. Anal. Bioanal. Chem. 410, 5373-5389.

55. ZHAN, J., X.-J. YU, Y.-Y. ZHONG, Z. T. ZHANG, X. M. CUI, J. F. PENG, R. FENG, X. T. LIU and Y. ZHU (2012): Generic and rapid determination of veterinary drug residues and other contaminants in raw milk by ultra performance liquid chromatography-tandem mass spectrometry. J. Chromatogr. B 906, 48-57.

56. ZHU, W., J. YANG, Z. WANG, C. WANG, Y. LIU and L. ZHANG (2016): Rapid determination of 88 veterinary drug residues in milk using automated Turbo Flow online clean-up mode coupled to liquid chromatography-tandem mass spectrometry. Talanta 148, 401-411. 


\section{Monitoring of pharmacologically active substances in milk in the European Union}

Nina BILANDŽIĆ* ${ }^{*}$ PhD, Grad. Biotechnol. Eng., Scientific Advisor, Ivana VARENINA, PhD, Grad. Biotechnol. Eng., Božica SOLOMUN KOLANOVIĆ, PhD, Grad. Food Technol. Eng., Đurđica BOŽIĆ LUBURIĆ, Grad. Biotechnol. Eng., Ines VARGA, Mag. Appl. Chem., Croatian Veterinary Institute, Zagreb, Croatia

The production of safe, high quality milk is a key aspect of public health in the European Union (EU). Frequent use of pharmacologically active substances in clinical practice on cattle farms results in the appearance of their residues in a variety of food products, including milk. The most commonly used drugs in the dairy industry are the antibiotics tetracyclines and beta-lactams, used against the pathogenic agents of mastitis. The use of veterinary medicines must be carefully optimized to protect consumers from potential adverse toxic effects. Another major problem is the development of resistance in the consumer that causes the failure of antibiotic therapies, especially against dangerous pathogenic strains of microorganisms. Today, most EU Member States are increasing milk production. The largest milk producers in the EU are Germany, France and the United Kingdom, while over the past 3 years, milk production has been declining in Croatia. EU Member States are seeking to control residues of pharmacologically active substances in milk using selective, sensitive and precise analytical methods. Liquid chromatography coupled with tandem mass spectrometry (LC-MS/MS) is the most commonly used instrumental analytical technique for the determination of residues of these substances in milk. Today, multi-methods have been developed using LC-MS/MS that allow for the identification of 160 or more compounds. In order to protect consumer health, EU Member States carry out controls on pharmacologically active substances in milk as part of their national residue monitoring plans (NRMP). The control of pharmacologically active substances is based on the defined maximum residue levels of those substances (MRL). The European Food Safety Authority (EFSA) collects control data from all EU Member States analysed under the NRMP and produces a joint report each year. Within the NRMP plans of EU Member States, non-compliant results of $0.115 \%, 0.128 \%$ and $0.304 \%$ were found for pharmacologically active substances in 2015, 2016 and 2017, respectively. Most of the non-compliant results pertain to the group of antibacterial substances (B1) and nonsteroidal anti-inflammatory drugs (B2e). In the antibacterial group, a total of $48.2 \%$ of non-compliant beta-lactams were detected in all three years. In 2017, the largest number of non-conforming results was related to nonsteroidal anti-inflammatory drugs (54.5\%), i.e. in this group $90.5 \%$ of non-compliant results were found for salicylic acid.

Key words: pharmacologically active substances; veterinary drugs; milk; milk control; European Union 